\title{
Endogenous histamine in the medial septum-diagonal band complex increases the release of acetylcholine from the hippocampus: a dual-probe microdialysis study in the freely moving rat
}

\author{
Lucia Bacciottini, Maria Beatrice Passani, Lisa Giovannelli, lacopo Cangioli, Pier Francesco Mannaioni, \\ Walter Schunack ${ }^{1}$ and Patrizio Blandina \\ Dipartimento di Farmacologia Preclinica e Clinica, Universitá di Firenze, V.le G. Pieraccini 6, 50139 Firenze, Italy \\ ${ }^{1}$ Institut für Pharmazie, Freie Universität Berlin, Germany
}

Keywords: c-fos, histamine $\mathrm{H}_{1}$ receptors, histamine $\mathrm{H}_{2}$ receptors, histamine $\mathrm{H}_{3}$ receptors

\begin{abstract}
The effects of histaminergic ligands on both ACh spontaneous release from the hippocampus and the expression of $c$-fos in the medial septum-diagonal band (MSA-DB) of freely moving rats were investigated. Because the majority of cholinergic innervation to the hippocampus is provided by MSA-DB neurons, we used the dual-probe microdialysis technique to apply drugs to the MSA$\mathrm{DB}$ and record the induced effects in the projection area. Perfusion of MSA-DB with high- $\mathrm{KCl}$ medium strongly stimulated hippocampal ACh release which, conversely, was significantly reduced by intra-MSA-DB administration of tetrodotoxin. Histamine or the $\mathrm{H}_{2}$ receptor agonist dimaprit, applied directly to the hippocampus, failed to alter ACh release. Conversely, perfusion of MSA-DB with these two compounds increased ACh release from the hippocampus. Also, thioperamide and ciproxifan, two $\mathrm{H}_{3}$ receptor antagonists, administered into MSA-DB, increased the release of hippocampal ACh, whereas R- $\alpha$-methylhistamine, an $\mathrm{H}_{3}$ receptor agonist, produced the opposite effect. The blockade of MSA-DB $\mathrm{H}_{2}$ receptors, caused by local perfusion with the $\mathrm{H}_{2}$ receptor antagonist cimetidine, moderated the spontaneous release of hippocampal ACh and antagonized the facilitation produced by $\mathrm{H}_{3}$ receptor antagonists. Triprolidine, an $\mathrm{H}_{1}$ receptor antagonist, was without effect. Moreover, cells expressing c-fos immunoreactivity were significantly more numerous in ciproxifan- or thioperamide-treated rats than in controls, although no colocalization of anti-c-fos and anti-ChAT immunoreactivity was observed. These results indicate a role for endogenous histamine in modulating the cholinergic tone in the hippocampus.
\end{abstract}

\section{Introduction}

Hippocampal ACh release increases during various behaviours, such as sensory stimulation (Nilsson et al., 1990; Inglis \& Fibiger, 1995), feeding and drinking (Mark et al., 1992), wakefulness (Mizuno et al., 1994), exploratory activity (Aloisi et al., 1997; Ceccarelli et al., 1999) and contextual fear conditioning (Nail-Boucherie et al., 2000). The functional significance of these increases is not clear yet; nevertheless, basic and clinical studies have long recognized the importance of cholinergic mechanisms operating within the medial septum-banda diagonalis (MSA-DB) complex in cognitive processes (Everitt \& Robbins, 1997; Pepeu \& Blandina, 1998). As a general rule, increases of hippocampal ACh release improved performances in hippocampal-related memory tasks (Givens \& Olton, 1994; Givens \& Sarter, 1997; Dickinson-Anson et al., 1998). Conversely, lesions of the fimbria-fornix, which conveys MSA-DB cholinergic fibres to the hippocampus (Lewis \& Shute, 1967), impaired performances in the same tasks (Brito \& Brito, 1990), possibly by preventing behaviourinduced increases of hippocampal ACh (Nilsson et al., 1990). Indeed, hippocampal ACh release depends upon impulse flow in neurons localized in the MSA-DB, which provide the cholinergic innervation

Correspondence: Dr Patrizio Blandina, as above.

E-mail: blandina@pharm.unifi.it

Received 1 October 2001, revised 6 March 2002, accepted 2 April 2002 to the hippocampus (Mesulam et al., 1983; Nicoll, 1985; Gaykema et al., 1990). Several neurotransmitters modulate the activity of these neurons, thus influencing learning and memory processes (Decker \& McGaugh, 1991; Moor et al., 1998; Passani \& Blandina, 1998). The current study focuses on the neuromodulatory action of histamine, which is released from axon varicosities of neurons located in the tuberomammillary nucleus of the hypothalamus (Panula et al., 1984; Watanabe et al., 1984). These cells send efferents to brain regions (Takeda et al., 1984; Wada et al., 1991) and, in the MSA-DB, histaminergic projections create dense networks of fibres (Inagaki et al., 1988; Panula et al., 1989). Histamine exerts its effects in the CNS by binding to its own specific receptors $\mathrm{H}_{1}, \mathrm{H}_{2}$ and $\mathrm{H}_{3}$, and to the polyamine site on the NMDA receptor complex (Brown et al., 2001). An early study indicates that ACh release from the CA1-CA3 region of hippocampus of urethane-anaesthetized rats could be modulated by endogenous histamine (Mochizuki et al., 1994). Indeed, an electrical stimulation applied to the tuberomammilary nucleus greatly increased histamine and ACh release from both MSADB and hippocampus. ACh release was inhibited by i.p. administration of zolantidine, an $\mathrm{H}_{2}$ receptor antagonist (Calcutt et al., 1988), but not of mepyramine, an $\mathrm{H}_{1}$ receptor antagonist (Ison \& Casy, 1971), thus suggesting an $\mathrm{H}_{2}$ receptor involvement. However, systemic drug injections do not reveal sites of action, whereas 


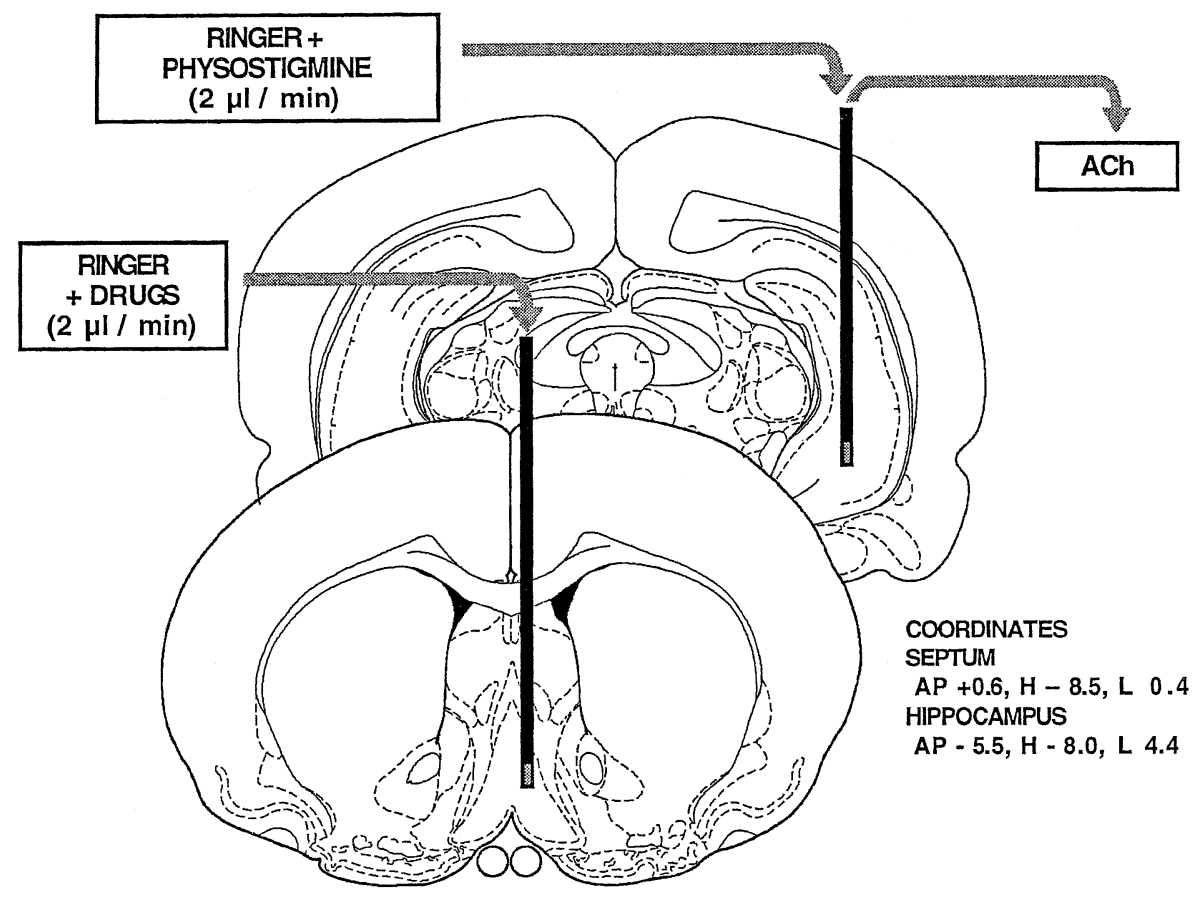

FIG. 1. Schematic diagram showing the position of the dialysis membrane in the MSA-DB and the hippocampus.

localized infusions of drugs to specific brain regions provide evidence of their site of action. In this study we used the dual-probe microdialysis technique to apply histaminergic drugs to the MSADB complex and to record the induced effects on ACh release from the projection area, the hippocampus, of freely moving rats. Moreover, it was investigated whether local administration of histaminergic drugs influenced c-fos protooncogene expression. cFos-like immunoreactivity may identify areas of neuronal activity and map functionally related neuronal pathways. Some of these results have been reported in abstract form (Bacciottini et al., 1999).

\section{Materials and methods}

\section{Animal housing}

Male Wistar rats (225-275 g body weight) were housed in groups of three in a temperature-controlled room $\left(20-24{ }^{\circ} \mathrm{C}\right)$, allowed free access to food and water, and kept on a 12-h light : 12-h dark cycle.

All the experiments were performed in strict compliance with the EEC recommendations for the care and use of laboratory animals (86/ 609/CEE), and were approved by the Animal Care Committee of the Dipartimento di Farmacologia Preclinica e Clinica of the Universitá di Firenze.

\section{Surgery and microdialysis}

The rats were anaesthetized with chloral hydrate (400 mg/kg i.p.) and placed in a stereotaxic frame (Stellar, Stoelting Co., Wood Dale, IL, USA). Each rat was implanted with vertical microdialysis probes in both the MSA-DB to deliver drugs locally, and the ipsilateral hippocampus to measure the output of ACh (Fig. 1). In a subset of experiments rats were implanted with a single probe in the hippocampus to investigate the effects of local drug administration on hippocampal ACh release. The microdialysis tubes were made of AN 69 membrane (Dasco, Italy), $220 \mu \mathrm{m}$ internal diameter and
$310 \mu \mathrm{m}$ external diameter, molecular weight cut-off $15000 \mathrm{Da}$. The coordinates used for the implantation of the microdyalisis tubes were as follows: for the hippocampus $\mathrm{AP}-5.5 \mathrm{~mm}, \mathrm{~L} 4.4$ and $\mathrm{H}-8 \mathrm{~mm}$ from bregma; for the MSA-DB AP $-0.6 \mathrm{~mm}$, L 0.4 and $\mathrm{H}-8.5 \mathrm{~mm}$. All coordinates (Paxinos \& Watson, 1982) were measured on the bone surface and referred to bregma, with bregma and lambda on a horizontal plane. Both cannulae were fixed to the skull with acrylic dental cement. After surgical manipulations rats were replaced in cages (one rat per cage) to recover from surgery.

The microdyalisis experiments were performed $24 \mathrm{~h}$ after surgery. The microdialysis probes were perfused at a rate of $2 \mu \mathrm{L} / \mathrm{min}$ using a microperfusion pump (Carnegie Medicine, mod. CMA/100, Sweden) with Ringer's solution (in mM: $\mathrm{NaCl}, 147 ; \mathrm{CaCl}_{2}, 2.5 ; \mathrm{KCl}, 3.0$; $\mathrm{pH}$ 7.0). To recover detectable dialysate concentrations of $\mathrm{ACh}$, a cholinesterase inhibitor (physostigmine sulphate, $7 \mu \mathrm{M}$ ) was added to the medium perfusing the hippocampus, but not to that perfusing the MSA-DB. Solutes < 15.000 Da molecular weight were allowed to cross the dialysis membrane according to their concentration gradient. Hence, both suitable endogenous molecules and exogenous compounds could feasibly be collected and administered, respectively. Drugs, alone or in combination, were dissolved into the MSA$\mathrm{DB}$ perfusing medium. Drug addition did not modify the $\mathrm{pH}$ of the medium. After an equilibration period of $60 \mathrm{~min}, 40-\mu \mathrm{L}$ fractions (resulting from 20-min intervals of perfusion) were collected. Rat MSA-DB was perfused with control medium in the first four fractions to measure hippocampal ACh spontaneous release; drugs were then added to the medium. Accurate placement of microdialysis membranes was verified post-mortem by observation under light microscopy visualization (Leitz, Dialva EB) of coronal sections cut through the probe paths. China ink $(5 \mu \mathrm{L})$ was injected through the probes at the end of each experiment to rats anaesthetized with urethane $(1.2 \mathrm{~g} / \mathrm{kg}$ i.p. $)$, before decapitation. Data from rats in which the membranes were not correctly positioned (fewer than $10 \%$ of the animals) were discarded. 


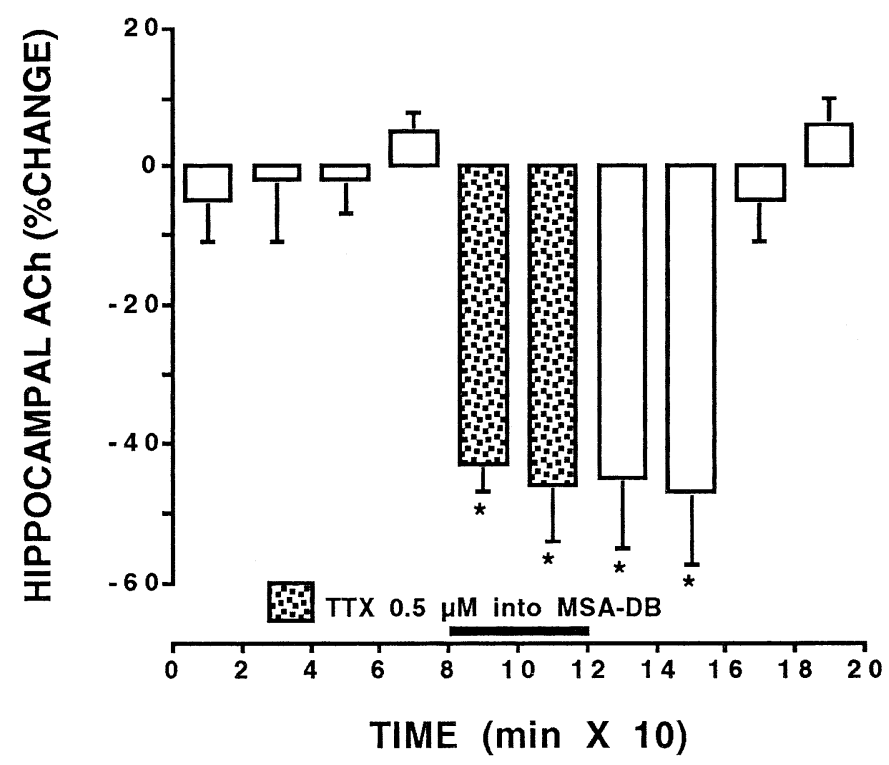

FIG. 2. Influence of administration into MSA-DB of TTX on spontaneous release of $\mathrm{ACh}$ from the hippocampus of freely moving rats. Twenty-four hours after implantation of the dialysis fibres, ACh was measured in hippocampal fractions collected every $20 \mathrm{~min}$ beginning $60 \mathrm{~min}$ after the onset of the perfusion. Spontaneous release of ACh was calculated for each experiment by averaging the mean of the four initially collected 20-min samples of perfusate, and $\mathrm{ACh}$ release was expressed as percentage of its spontaneous release value. At $40 \mathrm{~min}, 0.5 \mu \mathrm{M}$ TTX was introduced into the MSA-DB perfusing medium for $40 \mathrm{~min}$. The mean spontaneous release was $0.51 \pm 0.21 \mathrm{pmol} / 20 \mathrm{~min}(n=4)$. The bar shows the period of TTX application. Shown are means \pm SEM of four experiments. $* P<0.05$ vs. last sample before TTX treatment (ANOVA and Scheffé's test).

\section{Assay and quantification of ACh}

ACh was determined by HPLC-electrochemical detection as described previously (Giorgetti et al., 2000). The HPLC apparatus consisted of a pump (Mod. 1350, Bio-Rad, Richmond, CA, USA), a presaturation column (Chromspher $5 \mathrm{C} 18,100 \times 3 \mathrm{~mm}$, Chrompack, Middleburg, The Netherlands), an injector (Mod. 7125, Rhehodyne, Cotati, CA, USA), a guard column (reverse phase), an analytical column (Chromspher $5 \mathrm{C} 18,100 \times 3 \mathrm{~mm}$, Chrompack), an enzyme reactor $(10 \times 2.1 \mathrm{~mm}$, Chrompack), an electrochemical detector (Mod. LC4C, BioAnalytical System, West Lafayette, IN, USA) and a Perkin Elmer chart recorder. Briefly, ACh was separated on the cation exchange column. ACh was hydrolysed by acetylcholinesterase to form acetate and choline in the postcolumn enzyme reactor, then choline was oxidized by choline oxidase to produce betaine and hydrogen peroxide. Hydrogen peroxide was detected with a platinum electrode with the potential set at $0.5 \mathrm{~V}$. Peaks were identified by comparison of their retention times with those of the standards. The levels of $\mathrm{ACh}$ in the perfusates were calculated by comparison of sample peak heights with external standard peak height and expressed as pmol/20 min. Calibration curves for ACh were constructed by plotting the heights of peaks against the concentrations. Regression lines were then calculated and determination of unknown samples was carried out by the method of inverse prediction. The sensitivity limit was $500 \mathrm{fmol}$. ACh spontaneous release was calculated for each experiment by averaging the mean of the four initially-collected 20min samples of perfusate. ACh release was expressed as a percentage of its spontaneous release value. All values are expressed as means \pm SEM, and the number of experiments $(n)$ is also indicated. The in vitro recovery of $\mathrm{ACh}$ from the dialysis membrane was $\approx 60 \%$ at room temperature. Values reported here are not corrected for recovery.

\section{C-Fos procedure}

In immunohistochemical experiments, drugs dissolved in physiological saline were injected under general anaesthesia (chloral hydrate, $400 \mathrm{mg} / \mathrm{kg}$ i.p.) in the MSA-DB of rats restrained in a stereotaxic apparatus. The same coordinates were used as for the implantation of the microdialysis probes according to Paxinos \& Watson (1982). The tip of the needle was placed $7.5 \mathrm{~mm}$ ventral to bregma. The injection needle (outside diameter $0.3 \mathrm{~mm}$ ) was connected with a short piece of polyethylene tubing to a Hamilton syringe that was fixed to an electrode holder. Solutions $(0.5 \mu \mathrm{L}$ per side) were injected over a 1-min period and the needle was left in place for $2 \mathrm{~min}$ before withdrawing it. Control groups received injections of saline. Two hours after drug injections, rats were perfused transcardially with ice-cold $4 \%$ paraformaldehyde. The brains were removed and postfixed in the $4 \%$ paraformaldehyde for $2 \mathrm{~h}$ and then immersed in $18 \%$ sucrose for $24 \mathrm{~h}$. Coronal sections were cut at $40 \mu \mathrm{m}$ on a freezing cryostat, and were collected in phosphate-buffered saline (PBS) until processed for immunohistochemistry. Free-floating sections were incubated in anti c-fos polyclonal antibodies 1: 1500 in PBS containing 0.3\% Triton X100 (Sigma) and $5 \mathrm{mg} / \mathrm{mL}$ bovine serum albumin (BSA), overnight. The immunoreactive product was detected with the avidin-biotin peroxidase system (Vectastain kit; Vector Laboratories, Burlingame, CA, USA), as described previously (Giovannelli et al., 1990). After washing with PBS, sections were mounted on gelatin-coated slides, dehydrated in increasing concentrations of ethanol and coverslipped. In double labelling experiments, after c-fos immunostaining, sections were incubated in polyclonal anticholine acetyltransferase (ChAT) antibodies (Chemicon; Temecula, CA, USA) dissolved 1:1000 in PBS plus Triton-X 100 and $5 \mathrm{mg} / \mathrm{mL}$ BSA, overnight. Sections were washed in PBS, incubated in Cy3-conjugated antirabbit secondary antibodies (Chemicon), mounted on gelatin-coated slides and coverslipped with $70 \%$ glycerol in PBS. The fluorescent immunoreaction product was observed with a Zeiss microscope equipped for epifluorescence.

\section{Chemicals}

The substances used in this study included histamine hydrochloride, tetrodotoxin (Sigma Chemical Company Ltd, UK); dimaprit dihydrochloride, cimetidine (R)- $\alpha$-methylhistamine dihydrochloride, physostigmine sulphate, thioperamide maleate, triprolidine dihydrochloride (R.B.I., Natick, MA, USA); ciproxifan was provided by Dr W. Schunack. All other reagents and solvents were of HPLC grade or the highest grade available (Sigma).

\section{Statistical analysis}

All values are expressed as means \pm SEM and the number of experiments $(n)$ is also indicated. Comparisons between two means were performed by Student's $t$-test. Differences among groups were first determined by a one-way or a two-way analysis of variance (ANOVA) followed by Bonferroni's or Scheffé's test, as appropriate. Scheffé's procedure for post hoc comparisons performed all possible comparisons of the means. For the purposes of clarity and biological relevance, we report in figures and figure legends only the significant differences vs. the last sample before drug treatment. For all statistical tests, $P<0.05$ was considered significant. Statistical analysis was performed using StatView (Abacus Concepts, Inc., Berkeley, CA, USA) and GraphPad Prism (GraphPad Software, Inc., San Diego, CA, USA). 


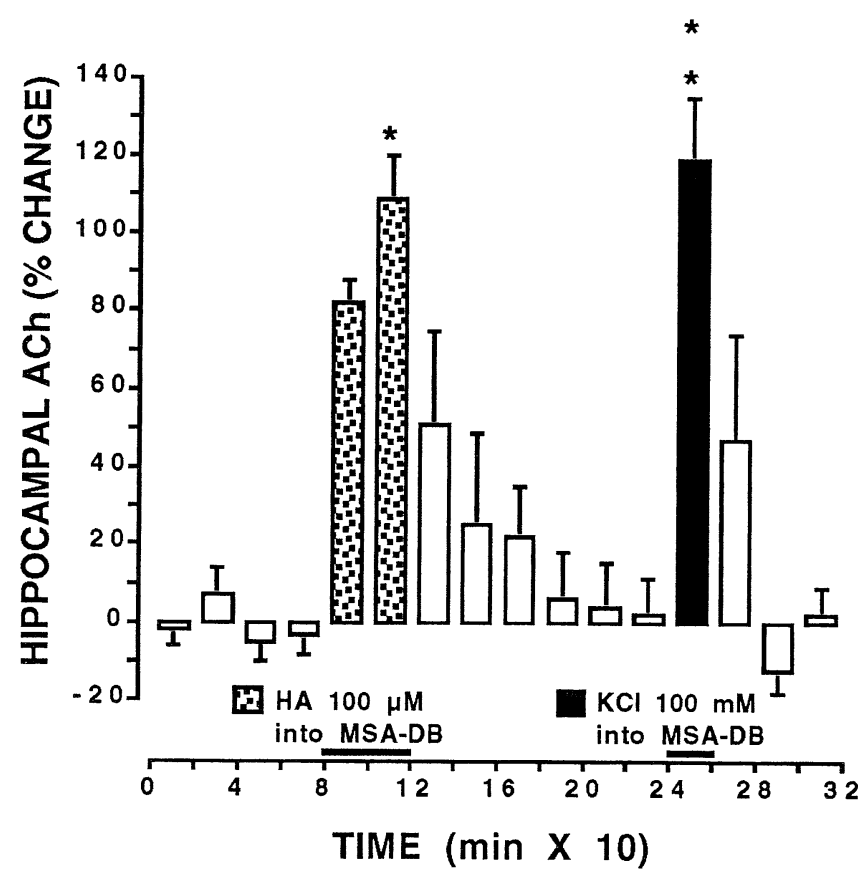

FIG. 3. Influence of administration into MSA-DB of histamine (HA) and $100 \mathrm{mM} \mathrm{KCl}$ on spontaneous release of $\mathrm{ACh}$ from the hippocampus of freely moving rats. Methods are identical to those described for Fig. 2. At $80 \mathrm{~min}$, histamine $(100 \mu \mathrm{M})$ was administered for $40 \mathrm{~min}$ through the dialysis fibre into the MSA-DB. At $240 \mathrm{~min}$ the NBM perfusing medium was changed from 4 to $100 \mathrm{mM} \mathrm{KCl}$ for $20 \mathrm{~min}$. Isotonicity was mantained by reducing $\mathrm{NaCl}$ concentration. The mean spontaneous release was $0.64 \pm 0.1 \mathrm{pmol} / 20 \mathrm{~min}(n=4)$. The bars show the period of histamine and high- $\mathrm{KCl}$ medium applications. Shown are means \pm SEM of four experiments. $* P<0.05$ and $* * P<0.01$ vs. last sample before histamine application (ANOVA and Scheffé's test).

Computerized counts of the c-fos-positive nuclei were performed with Image-Pro Plus 3.0 by one of the experimenters unaware of the animals' treatments. Numbers of c-fos-positive nuclei are averages of at least two consecutive sections.

\section{Results}

\section{Effects of MSA-DB perfusion with medium containing $1 \mu \mathrm{M}$ tetrodotoxin on ACh release from rat hippocampus}

Twenty-four hours after surgery microdialysis probes were inserted in the implanted guide tubes both in the hippocampus and the MSA-DB. The one implanted in the hippocampus was perfused with Ringer's solution containing $7 \mu \mathrm{M}$ physostigmine, whereas that implanted in the MSA-DB was perfused with Ringer's solution without physostigmine (Fig. 1). After 60 min of equilibration, the rat hippocampus spontaneously released $\mathrm{ACh}$ at stable rates, $0.79 \pm 0.05 \mathrm{pmol} /$ $20 \mathrm{~min}(n=62)$. Spontaneous release of $\mathrm{ACh}$ was calculated for each experiment by averaging the mean of the four initially-collected 20-min samples of hippocampal perfusate, and did not decrease significantly with time.

The infusion of $0.5 \mu \mathrm{M}$ tetrodotoxin (TTX), a voltage-dependent $\mathrm{Na}^{+}$-channel blocker, for $80 \mathrm{~min}$ into the MSA-DB through the dialysis probe reduced hippocampal ACh spontaneous release by $\approx 50 \%$ (Fig. 2). Spontaneous release averaged $0.51 \pm 0.21 \mathrm{pmol} /$ $20 \min (n=4)$. After TTX was withdrawn from septum-perfusing

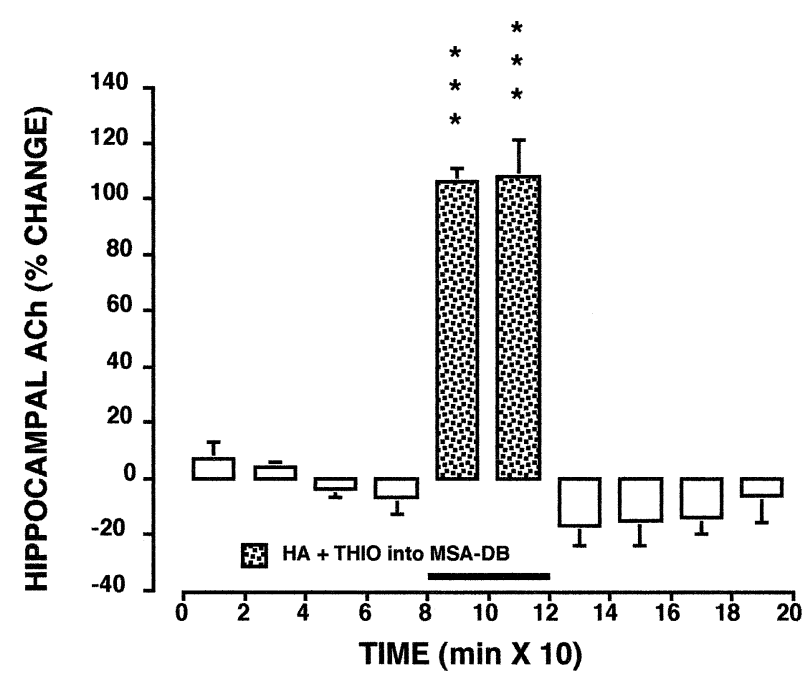

FIG. 4. Influence of simultaneous administration into MSA-DB of $100 \mu \mathrm{M}$ histamine (HA) and $300 \mathrm{nM}$ thioperamide on spontaneous release of ACh from the hippocampus of freely moving rats. Methods are identical to those described for Fig. 2. At $80 \mathrm{~min}$, histamine $(100 \mu \mathrm{M})$ and thioperamide $(300 \mathrm{nM})$ were administered for $40 \mathrm{~min}$ through the dialysis fibre into the MSA-DB. The mean spontaneous release was $0.31 \pm 0.03 \mathrm{pmol} / 20 \mathrm{~min}$ $(n=3)$. The bars show the period of histamine and thioperamide applications. Shown are means \pm SEM of three experiments. $* * * P<0.001$ vs. last sample before drug application (ANOVA and Scheffé's test).

medium, ACh release returned slowly toward basal values (Fig. 2). During the exposure to TTX the rats appeared to be more active but did not show any abnormal behaviour.

MSA-DB perfusion with medium containing $100 \mu \mathrm{M}$ histamine or $100 \mathrm{mM} \mathrm{KCl}$ increased the spontaneous release of $\mathrm{ACh}$ from the hippocampus.

Introduction of $100 \mu \mathrm{M}$ histamine into the medium perfusing the MSA-DB for 40 min increased significantly the release of ACh from the hippocampus (Fig. 3). The maximal effect $(109 \pm 11 \%$ ) was achieved in the second 20-min fraction collected after onset of MSADB perfusion with histamine. The level of the spontaneous release of hippocampal ACh was restored after withdrawal of histamine from MSA-DB perfusion medium (Fig. 3). A depolarization, induced by perfusing the MSA-DB for $20 \mathrm{~min}$ with a medium containing $100 \mathrm{mM} \mathrm{KCl}$, was conducted $120 \mathrm{~min}$ after the end of the perfusion with histamine, when hippocampal ACh release returned to basal levels (Fig. 3). It strongly stimulated the release of ACh from the hippocampus, producing a maximal increase of $119 \pm 16 \%$, which occurred in the 20-min fraction collected during the perfusion with $100 \mathrm{mM} \mathrm{KCl}$. The level of the spontaneous release of hippocampal ACh was restored during the subsequent MSA-DB perfusion with control medium (Fig. 3). During the perfusion with high- $\mathrm{KCl}$ medium, rats appeared to be more active but did not show any abnormal behaviour. The two consecutive exposures to histamine and $100 \mathrm{mM} \mathrm{KCl}$ released similar maximal amounts of $\mathrm{ACh}$, the mean ratio of histamine-evoked $\mathrm{ACh} / \mathrm{KCl}$-evoked $\mathrm{ACh}$ release being $0.9 \pm 0.1(n=4)$. The spontaneous release of hippocampal ACh in these experiments averaged $0.64 \pm 0.1 \mathrm{pmol} / 20 \mathrm{~min}(n=4)$.

The pattern of ACh release in response to MSA-DB perfusion with $100 \mu \mathrm{M}$ exogenous histamine did not change when thioperamide (300 nM) was infused into MSA-DB simultaneously with histamine (Fig. 4). It is noteworthy that exogenous histamine elicited maximal 


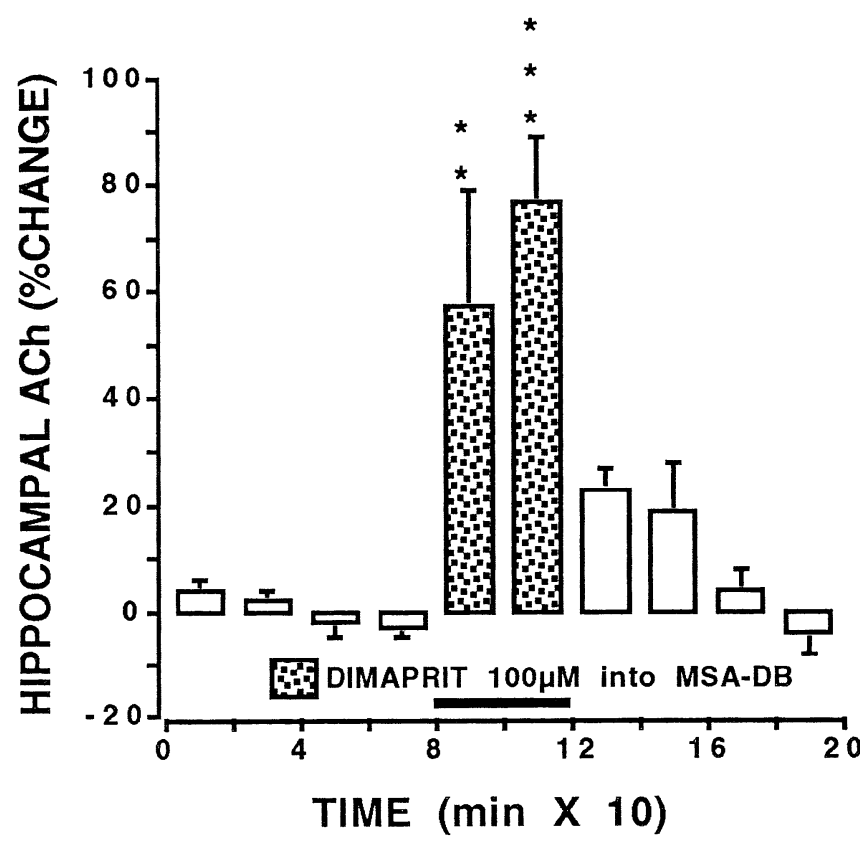

FIG. 5. Time course of release ACh from the hippocampus of freely moving rats evoked by administration into MSA-DB of dimaprit. Methods are identical to those described for Fig. 2. Dimaprit $(100 \mu \mathrm{M})$ was administered at $80 \mathrm{~min}$ into the MSA-DB through the dialysis probe for $40 \mathrm{~min}$. The mean spontaneous release was $0.63 \pm 0.2 \mathrm{pmol} / 20 \mathrm{~min}(n=6)$. The bar shows the period of dimaprit application. Shown are means \pm SEM of six experiments. $* * P<0.01$ and $* * * P<0.001$ vs. last sample before drug treatment (ANOVA and Scheffé's test)

increases of ACh release of similar amplitude either in the absence $(109 \pm 11 \%)$ or the presence $(109 \pm 13 \%)$ of thioperamide. The spontaneous release of hippocampal $\mathrm{ACh}$ in these experiments averaged $0.31 \pm 0.03 \mathrm{pmol} / 20 \mathrm{~min}(n=3)$.

\section{Opposite effects of local administration of histamine $\mathrm{H}_{2}$ and $\mathrm{H}_{3}$ receptor agonists into MSA-DB on the spontaneous release of hippocampal $A C h$}

Dimaprit added to the MSA-DB perfusing medium for $40 \mathrm{~min}$ at a concentration of $100 \mu \mathrm{M}$ significantly stimulated hippocampal ACh release, causing a maximal increase of $77 \pm 12 \%$ (Fig. 5). The spontaneous release of hippocampal ACh averaged $0.63 \pm 0.2 \mathrm{pmol} /$ $20 \mathrm{~min}(n=6)$. The maximal effect was always achieved in the second 20-min fraction collected after onset of the septum perfusion with dimaprit, and hippocampal ACh release was restored to control levels during subsequent MSA-DB perfusion with control medium (Fig. 5). Conversely, addition of $10 \mu \mathrm{M}$ R- $\alpha$-methylhistamine, an $\mathrm{H}_{3}$ receptor-selective agonist (Arrang et al., 1987) to the MSA-DB perfusing medium for 40 min resulted in a significant decrease in ACh spontaneous release from the hippocampus (Fig. 6). The response to R- $\alpha$-methylhistamine was of longer duration than the actual presence of the drug in the MSA-DB perfusing medium, and the maximal inhibition $(-47 \pm 4 \%$ ) was achieved in the 20 -min fraction collected after R- $\alpha$-methylhistamine was withdrawn from the perfusing medium. Eventually hippocampal ACh release returned to baseline (Fig. 6). In these experiments the spontaneous release of hippocampal ACh averaged $0.89 \pm 0.11 \mathrm{pmol} / 20 \mathrm{~min}(n=8)$.

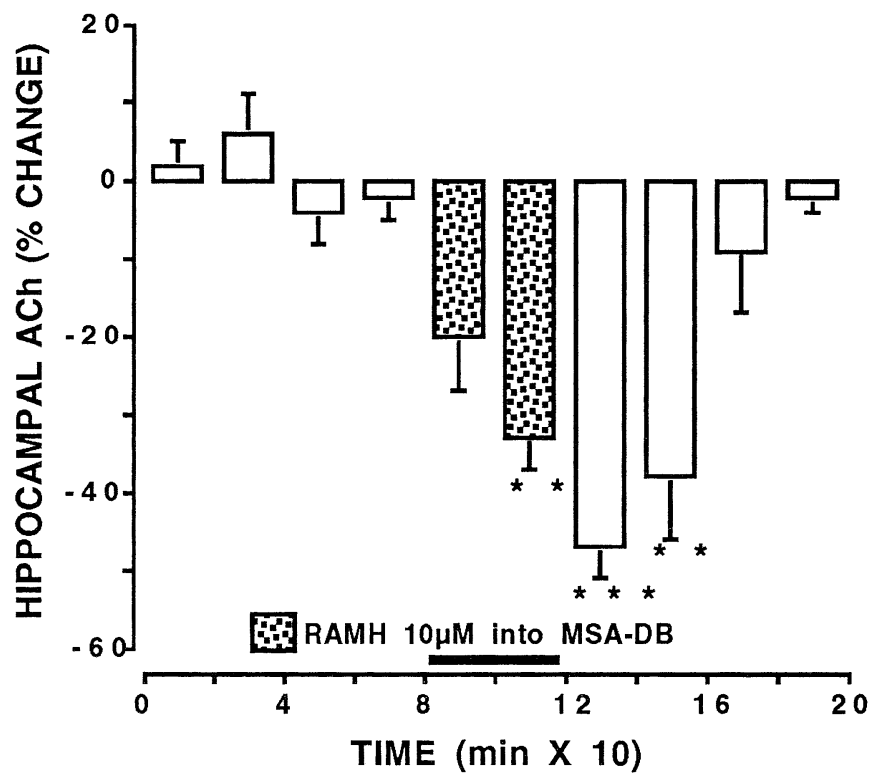

FIG. 6. Time course of release ACh from the hippocampus of freely moving rats evoked by administration of R- $\alpha$-methylhistamine into MSA-DB. Methods are identical to those described for Fig. 2. R- $\alpha$-methylhistamine $(10 \mu \mathrm{M})$ was administered at $80 \mathrm{~min}$ into the NBM through the dialysis probe and stopped at $120 \mathrm{~min}$. The bar shows the period of $\mathrm{R}-\alpha$ methylhistamine application. The mean spontaneous release was $0.89 \pm 0.11 \mathrm{pmol} / 20 \mathrm{~min}(n=8)$. Shown are means \pm SEM of eight experiments. $* * P<0.01, \quad * * * P<0.001$ vs. last sample before drug treatment (ANOVA and Scheffé's test).

Local administration of $\mathrm{H}_{3}$ receptor antagonists into MSA-DB increased the spontaneous release of ACh from the hippocampus

A significant increase in spontaneous release of ACh from the hippocampus was observed following the perfusion of the MSA-DB for $40 \mathrm{~min}$ with medium containing $0.3 \mu \mathrm{M}$ thioperamide, a selective $\mathrm{H}_{3}$ receptor antagonist (Arrang et al., 1987) (Fig. 7A). The maximal effect, $106 \pm 25 \%$ increase, was achieved very rapidly, and hippocampal ACh release was restored to control levels during subsequent MSA-DB perfusion with control medium (Fig. 7A). The spontaneous release of hippocampal ACh averaged $0.67 \pm 0.15 \mathrm{pmol} / 20 \mathrm{~min}(n=5)$. An identical MSA-DB perfusion with $0.05 \mu \mathrm{M}$ ciproxifan, another $\mathrm{H}_{3}$ receptor antagonist (Ligneau et al., 1998), elicited a $78 \pm 5 \%$ maximal increase of hippocampal ACh release with a time course comparable to that obtained with thioperamide (Fig. 8A). As for thioperamide, the ciproxifan effect was completely reversible. The spontaneous release of hippocampal ACh averaged $1.6 \pm 0.4 \mathrm{pmol} / 20 \min (n=7)$.

$\mathrm{H}_{2}$ receptor antagonism in the MSA-DB moderated the spontaneous release of ACh from the hippocampus and antagonized the facilitation produced by $\mathrm{H}_{3}$ receptor antagonists.

The effect of blocking $\mathrm{H}_{2}$ receptors on ACh spontaneous release from the hippocampus was tested by perfusing the MSA-DB with $100 \mu \mathrm{M}$ cimetidine, a selective $\mathrm{H}_{2}$ antagonist (Durant et al., 1977). Perfusion through the dialysis probe in the MSA-DB with $100 \mu \mathrm{M}$ cimetidine for $80 \mathrm{~min}$ decreased significantly, although only by $\approx 30 \%$, the spontaneous release of $\mathrm{ACh}$ from the hippocampus (Fig. 9). ACh release was restored to control levels during subsequent perfusion with control medium (Fig. 9). The spontaneous ACh release averaged $0.25 \pm 0.03 \mathrm{pmol} / 20 \mathrm{~min}(n=5)$. 


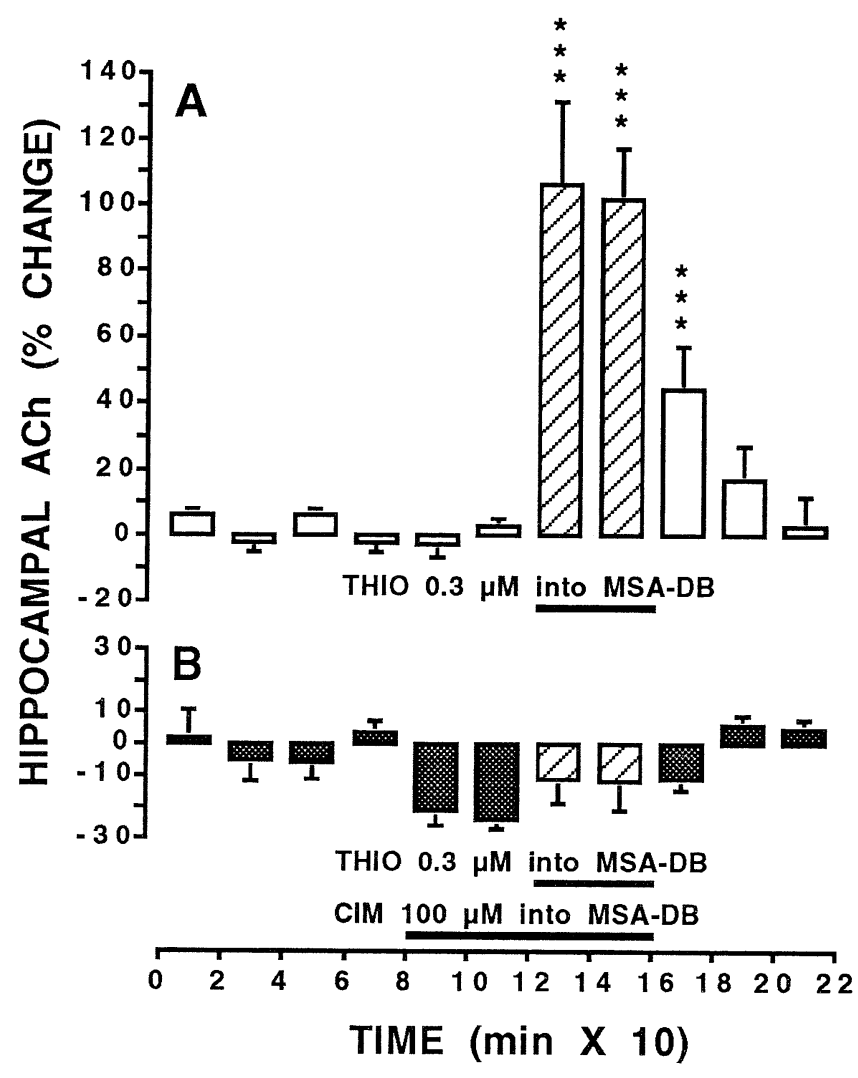

FIG. 7. Time course of release ACh from the hippocampus of freely moving rats evoked by administration into MSA-DB of thioperamide (THIO) in the absence (A)and in the presence (B)of cimetidine (CIM). Methods are identical to those described for Fig. 2. THIO $(0.3 \mu \mathrm{M})$ was administered at $120 \mathrm{~min}$ into the MSA-DB through the dialysis probe for $40 \mathrm{~min}$ in (A) the absence or (B) the presence of CIM $(100 \mu \mathrm{M})$ that was added to MSA-DB perfusing medium $40 \mathrm{~min}$ before administration of THIO. Hippocampal ACh spontaneous release averaged $0.67 \pm 0.15 \mathrm{pmol} / 20 \mathrm{~min}(n=5)$ in the experiments shown in panel $\mathrm{A}$, and $1.12 \pm 0.29 \mathrm{pmol} / 20 \mathrm{~min}(n=5)$ in those shown in panel B. The bars show the period of drug applications. There was a significant effect of Concentration $\times$ Time interaction $\left(F_{1,88}=11.15, \quad P<0.0001\right)$ and of drug treatment $\left(F_{1,10}=13.66\right.$, $P<0.0001$ ) (two-way ANOVA). Each point represents the mean value \pm SEM of (A) five and (B) five experiments. $* * * P<0.001$ vs. THIO + CIM (Bonferroni's test).

Figure 7B shows the time course of $\mathrm{ACh}$ release from the hippocampus evoked by local administration into MSA-DB of thioperamide in the presence of cimetidine. After collection of four 20-min baseline samples from the hippocampus, $100 \mu \mathrm{M}$ cimetidine was added to the MSA-DB perfusing medium alone for $40 \mathrm{~min}$, and then in combination with $0.3 \mu \mathrm{M}$ thioperamide for a further $40 \mathrm{~min}$. Washout with control medium was carried out for the final three 20min fractions. In the presence of cimetidine, the facilitatory effect of thioperamide on ACh release from hippocampus was completely abolished. There was a significant effect of both Concentration $\times$ Time interaction $\left(F_{1,88}=11.15, P<0.0001\right)$ and drug treatment $\left(F_{1,10}=13.66, P<0.0001\right.$; two-way ANOvA $)$. The seventh, eighth and ninth 20-min fractions shown in Fig. 7A were significantly different when compared to the corresponding 20-min fractions of Fig. 7B $(P<0.001$, Bonferroni's test). A similar effect was observed when ciproxifan was infused into the MSA-DB in the presence of cimetidine. Figure $8 \mathrm{~B}$ shows that the facilitatory effect of ciproxifan $(0.05 \mu \mathrm{M})$ on $\mathrm{ACh}$ release was fully counteracted by

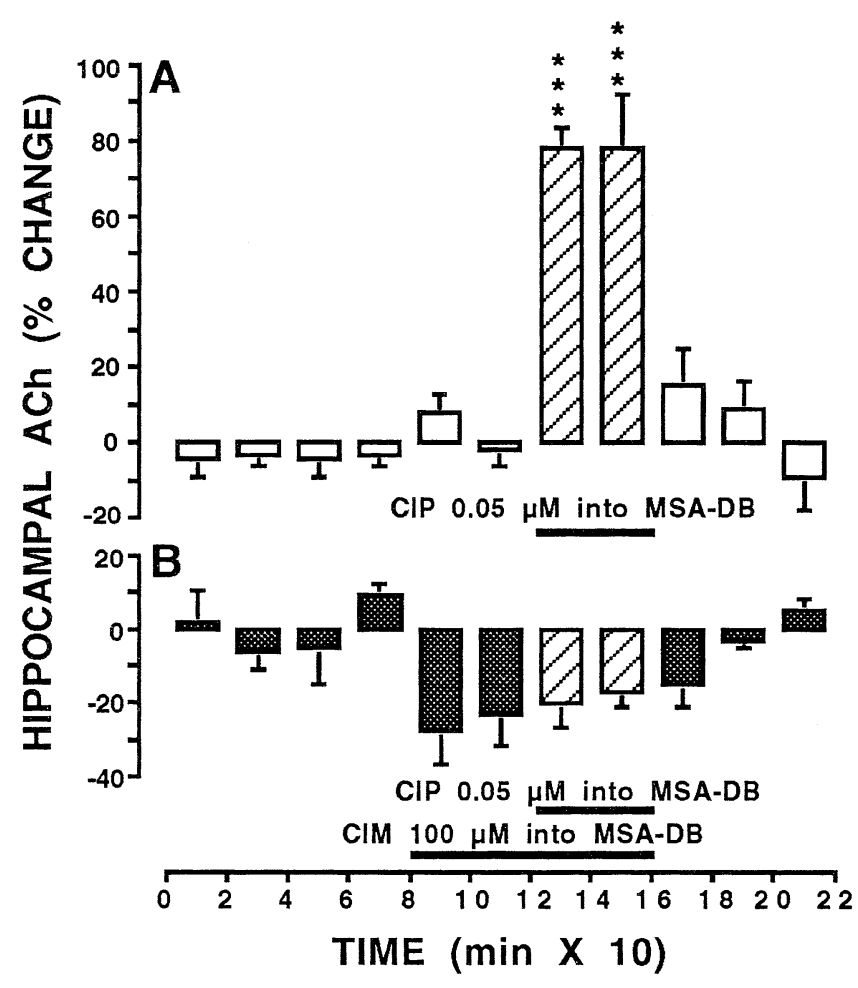

FIG. 8. Time course of release ACh from the hippocampus of freely moving rats evoked by administration into MSA-DB of ciproxifan (CIP) in (A)the absence and (B)the presence of cimetidine (CIM). Methods are identical to those described for Fig. 2. CIP $(0.05 \mu \mathrm{M})$ was administered at $120 \mathrm{~min}$ into the MSA-DB through the dialysis probe for $40 \mathrm{~min}$ in (A) the absence or (B) the presence of CIM $(100 \mu \mathrm{M})$ that was added to MSA-DB perfusing medium $40 \mathrm{~min}$ before administration of CIP. Hippocampal ACh spontaneous release averaged $1.6 \pm 0.4 \mathrm{pmol} / 20 \mathrm{~min}(n=7)$ in the experiments shown in panel $\mathrm{A}$, and $0.96 \pm 0.22 \mathrm{pmol} / 20(n=3)$ in those shown in panel B. The bars show the period of drug applications. There was a significant effect of Concentration $\times$ Time interaction $\left(F_{1,90}=7.904\right.$, $P<0.0001)$ and of drug treatment $\left(F_{1,9}=14.39, P<0.0001\right)$ (two-way ANOVA). Each point represents the mean value \pm SEM of (A) seven and (B) three experiments. $* * * P<0.001$ vs. CIP + CIM (Bonferroni's test).

cimetidine $(100 \mu \mathrm{M})$. There was a significant effect of both Concentration $\times$ Time interaction $\left(F_{1,90}=7.904, P<0.0001\right)$ and drug treatment $\left(F_{1,9}=14.39, P<0.0001\right)$ (two-way ANOVA). Both seventh and eighth 20-min fractions shown in Fig. 8A were significantly different when compared to the corresponding 20-min fractions of Fig. 8B $(P<0.001$, Bonferroni's test $)$. ACh spontaneous release averaged $1.12 \pm 0.29 \mathrm{pmol} / 20 \mathrm{~min}(n=5)$ in the experiments with thioperamide and cimetidine, and $0.96 \pm 0.22 \mathrm{pmol} /$ $20 \min (n=3)$ in those with ciproxifan and cimetidine.

\section{Local administration of triprolidine into MSA-DB failed to antagonize the release of hippocampal ACh elicited by thioperamide}

Perfusion of MSA-DB with $0.5 \mu \mathrm{M}$ triprolidine, an $\mathrm{H}_{1}$ receptor antagonist (Ison \& Casy, 1971), failed to alter ACh spontaneous release from the hippocampus during a 40-min perfusion. The changes in hippocampal ACh release were always within the range of variability $( \pm 15 \%)$ seen between individual 20-min collection periods during MSA-DB perfusion with control medium (data not shown). In these experiments the spontaneous release of hippocampal ACh averaged $0.60 \pm 0.04 \mathrm{pmol} / 20 \min (n=3)$. 


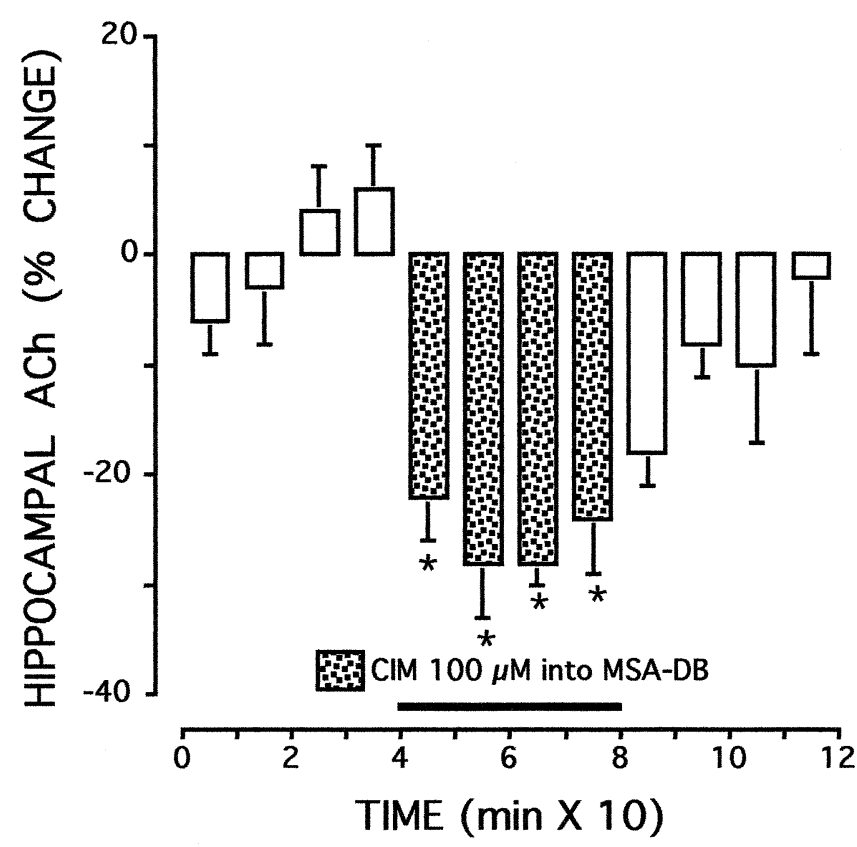

FIG. 9. Time course of release ACh from the hippocampus of freely moving rats evoked by administration into MSA-DB of cimetidine (CIM). Methods are identical to those described for Fig. 2. CIM $(100 \mu \mathrm{M})$ was administered at $80 \mathrm{~min}$ into the NBM through the dialysis probe for $40 \mathrm{~min}$. The mean spontaneous release was $0.77 \pm 0.08 \mathrm{pmol} / 20 \mathrm{~min}(n=5)$. The bar shows the period of cimetidine application. Shown are means \pm SEM of five experiments. ${ }^{*} P<0.05$ vs. last sample before drug treatment (ANOVA and Scheffé's test).

The effect of $0.5 \mu \mathrm{M}$ triprolidine on $0.3 \mu \mathrm{M}$ thioperamide-evoked release of hippocampal ACh was also examined. After collection of four 20-min baseline samples from the hippocampus, triprolidine was added to the MSA-DB perfusing medium alone for $40 \mathrm{~min}$, and then in combination with thioperamide for a further $40 \mathrm{~min}$ (Fig. 10). The presence of triprolidine failed to modify thioperamide-evoked release of hippocampal ACh (Fig. 10). In these experiments hippocampal ACh spontaneous release averaged $0.44 \pm 0.02 \mathrm{pmol} / 20 \mathrm{~min}$ $(n=3)$.

\section{Effects of hippocampal perfusion with medium containing $100 \mu \mathrm{M}$ histamine or dimaprit on ACh release from rat hippocampus}

Twenty-four hours after rats were implanted with a microdialysis probe in the hippocampus, the probe was perfused with Ringer's solution containing $7 \mu \mathrm{M}$ physostigmine. The introduction of $100 \mu \mathrm{M}$ histamine into hippocampal perfusing medium failed to alter ACh release from the hippocampus during a 40-min perfusion. The changes in hippocampal ACh release were always within the range of variability $( \pm 15 \%)$ seen between individual 20-min collection periods during hippocampal perfusion with control medium (data not shown). In these experiments hippocampal ACh spontaneous release averaged $0.71 \pm 0.09 \mathrm{pmol} / 20 \mathrm{~min}(n=5)$. Also, dimaprit, a highly selective $\mathrm{H}_{2}$ receptor agonist (Parson et al., 1977), added to the hippocampal-perfusing medium for $40 \mathrm{~min}$ at a concentration of $100 \mu \mathrm{M}$, failed to modify significantly hippocampal ACh release. The spontaneous release of hippocampal ACh averaged $0.76 \pm 0.19 \mathrm{pmol} / 20 \mathrm{~min}(n=4)$.

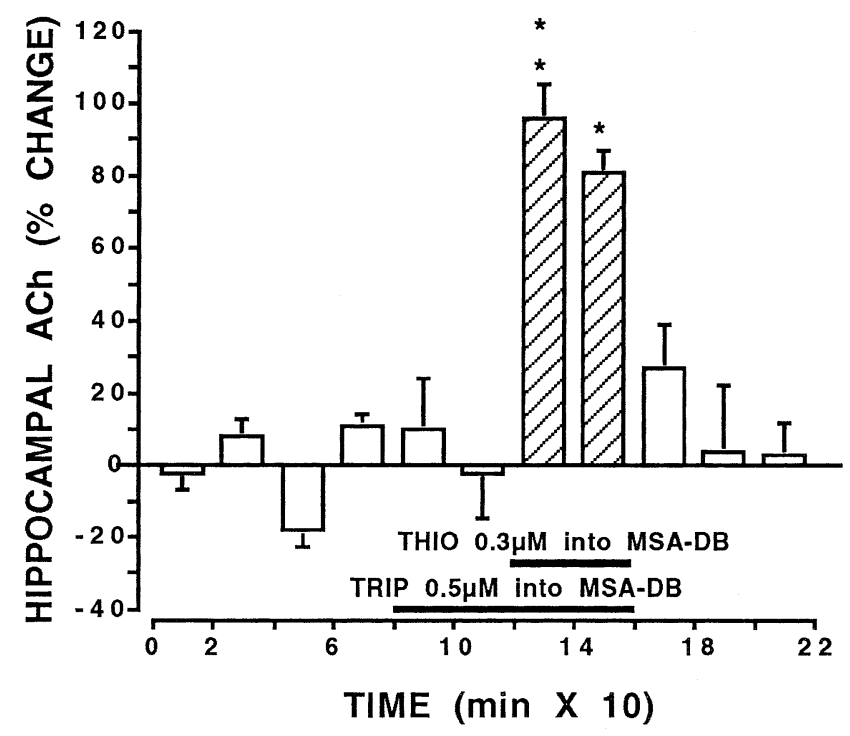

FIG. 10. Time course of release ACh from the hippocampus of freely moving rats evoked by administration of thioperamide (THIO) into MSA$\mathrm{DB}$ in the presence of triprolidine (TRIP). Methods are identical to those described for Fig. 2. THIO $(0.3 \mu \mathrm{M})$ was administered at $120 \mathrm{~min}$ into the MSA-DB through the dialysis probe for $40 \mathrm{~min}$ in the presence of TRIP $(0.5 \mu \mathrm{M})$ that was administered into MSA-DB for $40 \mathrm{~min}$ before administration of THIO. Hippocampal ACh spontaneous release averaged $0.44 \pm 0.02 \mathrm{pmol} / 20 \mathrm{~min}(n=3)$. The bars show the period of drug applications. Shown are means \pm SEM of three experiments. $* P<0.05$ and $* * P<0.01$ vs. last sample before drug treatment (ANOVA and Scheffé's test).

\section{Thioperamide and ciproxifan modulate $c$-fos expression in $M S A-D B$ neurons}

The counts were taken in sections close to the needle tip and involved the corresponding portions of MSA-DB. As shown in Fig. 11, cells expressing c-fos immunoreactivity were significantly more numerous in thioperamide- and ciproxifan-treated rats than in controls. The photomicrograph shows the cloud of c-fos-positive cell nuclei around the track of the needle tip in thioperamide-treated rats. Double labelling experiments with anti ChAT antibodies were carried out in a subset of experiments in an attempt to characterize the c-fos-positive cell. No colocalization of anti-c-fos and anti-ChAT immunoreactivity, though, was observed ( $n=3$; data not shown).

\section{Discussion}

This study demonstrates that histamine facilitates ACh release from the hippocampus through interactions with $\mathrm{H}_{2}$ receptors in the MSADB. Indeed, intra-MSA-DB, but not intrahippocampal, administration of exogenous histamine or of the $\mathrm{H}_{2}$ receptor-selective agonist dimaprit increased the spontaneous release of $\mathrm{ACh}$ from the hippocampus. Moreover, the blockade of $\mathrm{H}_{3}$ receptors in MSA-DB by thioperamide and ciproxifan indicates a role for endogenous histamine in modulating the cholinergic tone in the hippocampus. The effects of perfusion of MSA-DB with histaminergic drugs on the rate of hippocampal $\mathrm{ACh}$ spontaneous release were investigated by means of a dual-probe microdialysis method. Because both in rats and in humans projections from the MSA-DB provide the majority of cholinergic innervation to the hippocampus (Lewis et al., 1967; 


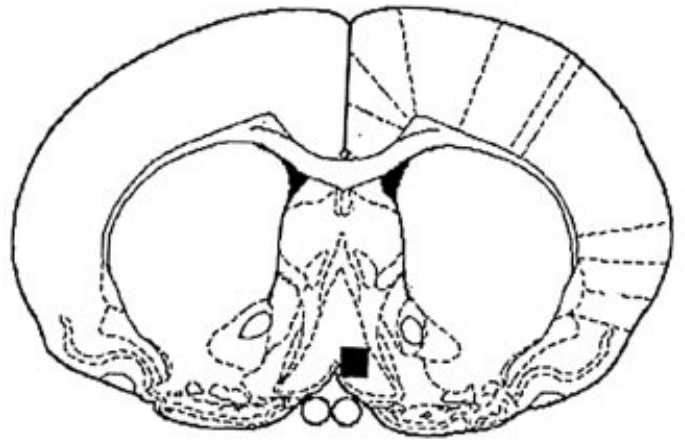

A

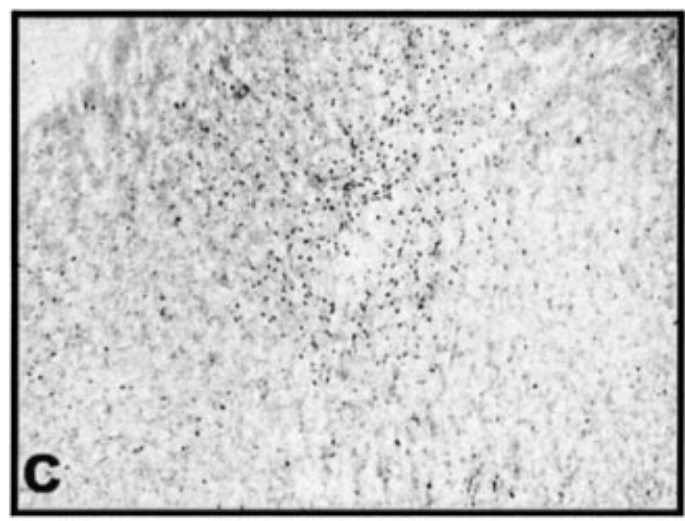

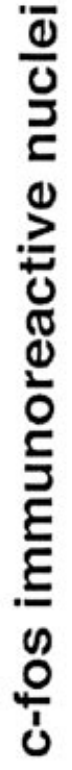

500
400
30
100

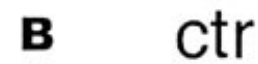

*

(3)

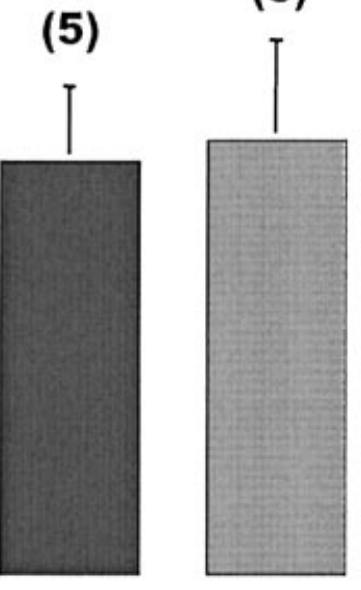

\section{thio cipro}

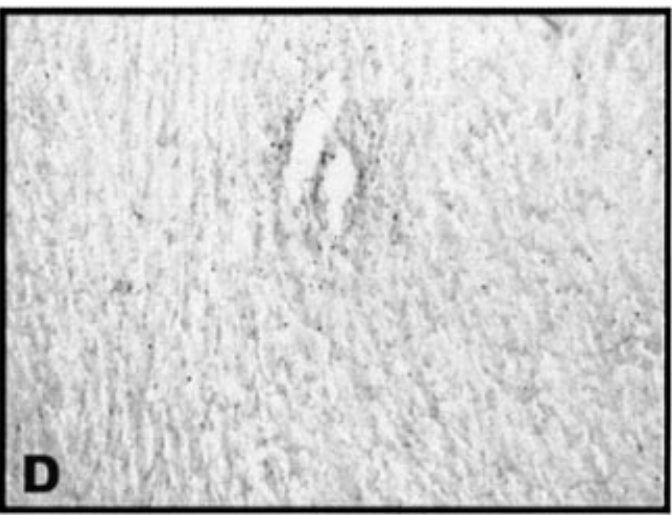

FIG. 11. Injections of $\mathrm{H}_{3}$ receptor antagonists in the septum increased the expression of c-fos. (A) Schematic drawing of a brain section through the MSA-DB showing the area sampled for c-fos-immunopositive nuclei (black square). (B) The number of cell nuclei expressing c-fos-like immunoreactivity was significantly higher in the septum of animals that received intraseptal injections of either thioperamide ( $3 \mu \mathrm{M})$ or ciproxifan $(500 \mathrm{nM})$. The number of c-fospositive cells is the average of at least two adjacent sections per animal. (C and D) Photomicrographs of c-fos-like immunoreactivity in the medial septum after (C) thioperamide and (D) saline injection. The track of the needle is visible at the centre of each photomicrograph. Shown are means \pm SEM of 3-5 experiments. $* P<0.05$ and $* * P<0.01$ vs. control (ANOvA and Scheffé's test).

Nyakas et al., 1987; De Lacalle et al., 1994), a first vertical microdialysis probe was implanted in the MSA-DB to deliver locally different drugs, and a second one was inserted in the hippocampus to measure ACh extracellular levels. The feasibility of such an approach was validated by the demonstration that hippocampal ACh extracellular levels depended on the activity of MSA-DB neurons. Indeed, when the $\mathrm{KCl}$ concentration in the MSA-DB perfusing medium was changed from 4 to $100 \mathrm{mM} \mathrm{KCl}$ for $20 \mathrm{~min}$, it elicited a pronounced and rapid increase in hippocampal ACh release. This concentration of $\mathrm{KCl}$ is only apparently very high, considering its rapid dilution into the extracellular fluid and the low recovery of the microdialysis membrane (Westerink \& de Vries, 1996). Conversely, administration of the nerve impulse blocker TTX into MSA-DB decreased ACh spontaneous release from the hippocampus by $>50 \%$, thus indicating the presence of spontaneous impulse activity in MSA-DB cholinergic neurons at rest. The increase of ACh release produced by $100 \mathrm{~mm}$
$\mathrm{KCl}$ suggests that in vivo the resting MSA-DB cholinergic neurons may increase their firing frequency according to the intensity of the stimulus. This evidence is consistent with the intrinsic membrane properties of these neurons described previously in electrophysiological studies (Segal, 1986; Gorelova \& Reiner, 1996; Wu et al., 2000). Therefore, the dual probe is a useful approach for investigating the neurochemical activity of the MSA-DB-hippocampal pathway, and infusion of TTX and high $\mathrm{KCl}$ is a reliable method for evaluating the implantation of the microdialysis probes, consistent with earlier observations in the nucleus basalis magnocellularis-cortical pathway (Cecchi et al., 2001).

The presence of physostigmine in the perfusion medium may be criticized because the cholinesterase inhibition might alter the modulation of ACh spontaneous release, as in the case of dopamine on striatal ACh release (DeBoer \& Abercrombie, 1996). However, the hippocampus, as well as the amygdala (Passani et al., 2001) and 
the cortex (Herrera-Marschitz et al., 1990; Consolo et al., 1994; Giovannini et al., 1998), release much lower levels of ACh than does the striatum, thus requiring the presence of cholinesterase inhibitors in the perfusion fluid. It is noteworthy that concentrations up to $0.5 \mu \mathrm{M}$ neostigmine, which is $\approx 10$ times more potent than physostigmine, failed to alter qualitatively cortical ACh release patterns in response to behavioural activation (Himmelheber et al., 1998).

The increase of ACh release caused by thioperamide or ciproxifan is attributable to blockade of $\mathrm{H}_{3}$ receptors localized in the MSA-DB. Indeed, comparable increases of hippocampal $\mathrm{ACh}$ release were elicited by MSA-DB perfusion with medium containing either $300 \mathrm{nM}$ thioperamide, a competitive antagonists at $\mathrm{H}_{3}$ receptors with $\mathrm{pA}_{2}$ values in cortical slices of 8.96 (Arrang et al., 1987), or $50 \mathrm{nM}$ ciproxifan, another highly selective $\mathrm{H}_{3}$-antagonist $\approx 10$ times more potent than thioperamide (Ligneau et al., 1998). Conversely, the histaminergic agonist R- $\alpha$-methylhistamine, added to the MSA-DB perfusing medium at a concentration selective for the $\mathrm{H}_{3}$ receptor (Arrang et al., 1987; Blandina et al., 1996), decreased significantly hippocampal ACh release. The $\mathrm{H}_{3}$ receptor was initially discovered on histaminergic neurons as a presynaptic autoreceptor whose activation inhibited, whilst its blockade increased, the release of histamine (Arrang et al., 1983). A physiological function of endogenous histamine in the control of hippocampal ACh release is indicated by the facilitation produced by thioperamide and ciproxifan. Indeed, the increase in hippocampal ACh release could be most simply explained by an interaction with $\mathrm{H}_{3}$ autoreceptors whose blockade may have produced an increase in endogenous histamine release. Therefore, the present study indicates that activation of histaminergic neurons projecting to the MSA-DB facilitates the cholinergic tone in the hippocampus. Postsynaptic $\mathrm{H}_{2}$ receptors appear to mediate this effect because pretreatment with cimetidine, at a concentration sufficient to fully block $\mathrm{H}_{2}$ receptors (Durant et al., 1977), completely abolished the effect of both thioperamide and ciproxifan. A different localization of $\mathrm{H}_{2}$ and $\mathrm{H}_{3}$ receptors is also suggested by the observation that exogenous histamine $(100 \mu \mathrm{M})$ produced increases in ACh release of similar amplitude either in the presence or in the absence of a concentration of thioperamide that fully blocks $\mathrm{H}_{3}$ receptors. Indeed, histamine showed higher affinity for the $\mathrm{H}_{3}$ (pD2 value of 7.4) than for the $\mathrm{H}_{2}$ receptor (pD2 value of 6.0) (Leurs et al., 1995); thus the increase in ACh release elicited by the infusion with $100 \mu \mathrm{M}$ exogenous histamine is the result of stimulation of both receptor types. It is conceivable that $\mathrm{H}_{3}$ receptors are localized on histaminergic terminals. However, a $100-\mu \mathrm{M}$ concentration of exogenous histamine fully activated postsynaptic $\mathrm{H}_{2}$ receptors, and any variation of endogenous histamine by $\mathrm{H}_{3}$ autoreceptor activation had no influence on $\mathrm{ACh}$ release. $\mathrm{H}_{2}$ receptor involvement is also supported by the observation that infusion of MSA-DB with a highly selective $\mathrm{H}_{2}$ receptor agonist, dimaprit (Parson et al., 1977), increased hippocampal ACh release with a pattern similar to that of exogenous histamine. MSA-DB displayed both $\mathrm{H}_{2}$ receptor binding and its gene transcripts (Vizuete et al., 1997; Karlstedt et al., 2001). These receptors are positively coupled with adenylyl cyclase (Johnson, 1982), and their activation in neurons led to mainly excitatory effects through blockade of calciumactivated potassium current and modulation of the hyperpolarization-activated cation channel (Brown et al., 2001). Stimulation of transmitter release by $\mathrm{H}_{2}$ receptor activation occurs in other brain regions, because $\mathrm{H}_{2}$ receptor activation released endogenous noradrenaline from rat hypothalamic slices (Blandina et al., 1989) and endogenous enkephalin from mouse striatum (Garbarg et al., 1991). Conversely, modulation of ACh release from the hippocampus did not involve $\mathrm{H}_{1}$ receptors because MSA-DB perfusion with the $\mathrm{H}_{1}$ antagonist triprolidine, at a concentration $>500$ times its $K_{d}$ for the $\mathrm{H}_{1}$ receptor (Ison \& Casy, 1971), failed to modify both spontaneous and thioperamide-evoked release of ACh.

In addition to preventing the stimulation elicited by $\mathrm{H}_{3}$ antagonists, intra-MSA-DB administration of cimetidine alone decreased hippocampal ACh spontaneous release, thus indicating that MSA-DB histaminergic input tonically facilitated hippocampal cholinergic activity. This hypothesis is consonant with the observation that R- $\alpha$ methylhistamine moderated hippocampal ACh release. This inhibition may depend on a decrease of endogenous histamine release due to activation of $\mathrm{H}_{3}$ autoreceptors. It is noteworthy that $\mathrm{H}_{3}$ receptors are present in the MSA-DB complex (Pollard et al., 1993), which exhibits moderate to dense levels of histaminergic fibres (Wouterlood et al., 1988; Panula et al., 1989). The tonic activation of $\mathrm{H}_{2}$ receptors was not detected in anaesthetized rats (Mochizuki et al., 1994), but differences in administration route of $\mathrm{H}_{2}$ receptor antagonists (systemically in Mochizuki's study and locally into the MSA-DB in the current study) could account for the discrepancy. Moreover, intrinsic properties of cholinergic septal neurons of anaesthetized rats differ from those of unanaesthetized rats. In anaesthetized rats, about half of these neurons fired rhytmically in single spikes or short bursts (Lamour et al., 1984; Dutar et al., 1986), whereas in awake rats the proportion of rhytmically bursting neurons is smaller and the mean spontaneous activity is higher (Lee et al., 1991; Sweeney et al., 1992).

Whether $\mathrm{H}_{2}$ receptors are located on cholinergic perikarya or on hypothetical interneurons is not clear yet. It has been reported that histamine depolarized MSA-DB cholinergic neurons in a slice preparation of rat brain, producing an increase in sodium conductance which led these neurons to threshold for firing spontaneous action potentials (Gorelova \& Reiner, 1996); this observation favours the hypothesis of a direct mechanism. However, this depolarization was attributed to $\mathrm{H}_{1}$ receptor activation, being significantly reduced by mepyramine and promethazine (Gorelova \& Reiner, 1996), whereas Mochizuki et al. (1994) and the current study failed to show any effect in modulating hippocampal $\mathrm{ACh}$ release by $\mathrm{H}_{1}$ receptor antagonists. One may argue that $\mathrm{H}_{1}$ receptor antagonists were employed in the study by Gorelova \& Reiner (1996) at concentrations to high for excluding $\mathrm{H}_{1}$-receptor-unrelated effects (Hill, 1990; Hill et al., 1997), but also another explanation could be offered for the lack of effect of $\mathrm{H}_{1}$ receptor antagonists in microdialysis studies. Depolarization induced by histamine was transient, desensitization within seconds being its prominent feature, and the excitation diminished despite continued application of histamine (Gorelova \& Reiner, 1996). If the effect on ACh release was transient as well and very short, it is possible that it became obscured during the attainment of the 20-min perfusion sample, thus explaining the lack of effects of $\mathrm{H}_{1}$ receptor blockade on hippocampal cholinergic activity.

Systemic administration of thioperamide increased whilst that of $\mathrm{R}-\alpha$-methylhistamine decreased ACh spontaneous release from the hippocampus of anaesthetized rats (Mochizuki et al., 1994). The current study extends these findings in freely moving rats, and demonstrates that histaminergic drugs acted in the MSA-DB complex. Indeed, the interaction between histaminergic and cholinergic systems occurs only at this level, because histamine and dimaprit locally applied to the hippocampus failed to alter extracellular levels of local ACh. The report that $\mathrm{H}_{3}$ receptor-elicited modulation of $\left[{ }^{3} \mathrm{H}\right]-$ ACh release from rat hippocampal slices was not detectable (AlvesRodrigues et al., 1998) agrees with our findings. Although the hippocampus receives only a weak histaminergic innervation (Wouterlood et al., 1988), in vitro and in vivo studies demonstrated 
that histamine exerts in this area many prominent effects which are likely to be important in the induction of synaptic plasticity and consolidation of memory (see review by Brown et al., 2001). In this regard, given that MAP kinase activation is necessary for synaptic plasticity (English \& Sweatt, 1996), the reports that histaminergic receptors are coupled to MAP-kinase signalling pathways in COS-7 cells (Drutel et al., 2001) and CA3 hippocampal neurons (Blandina et al., 2001) are intriguing.

The specific behavioural significance of the interactions between histaminergic and MSA-DB cholinergic systems remains to be explored, but a role in cognitive processes is suggested by the observation that post-training intraseptal injection of both $\mathrm{H}_{2}$ receptor agonists and $\mathrm{H}_{3}$ receptor antagonists improved retention in a T-maze avoidance task, whilst that of $\mathrm{H}_{3}$ receptor agonists and $\mathrm{H}_{2}$ receptor antagonists had the opposite effect (Flood et al., 1998). Post-training administration of these compounds excludes any influence of the treatment on acquisition and on other processes that indirectly affect learning (McGaugh \& Izquierdo, 2000). According to our findings, the improvement elicited by $\mathrm{H}_{2}$ receptor agonists and $\mathrm{H}_{3}$ receptor antagonists may reflect an enhanced release of hippocampal ACh, whilst cognitive deficits caused by $\mathrm{H}_{3}$ receptor agonists and $\mathrm{H}_{2}$ receptor antagonists may occur as a consequence of hippocampal cholinergic tone inhibition. The role of histamine as an important neurotransmitter in the mammalian brain and as a modulator of cognitive processes has recently gained attention (Leurs et al., 1998; Passani et al., 2000; Bacciottini et al., 2001), and the significance of interactions between histaminergic and cholinergic systems in learning and memory processes have been clearly demonstrated in the cortex (Blandina et al., 1996; Giovannini et al., 1999) and the amygdala (Passani et al., 2001).

Intraseptal administration of thioperamide or ciproxifan also increased the number of c-fos-immunopositive cells in MSA-DB. Expression of the c-fos gene is an indirect correlate of increased neuronal activity (Dragunow \& Faull, 1989; Herrera \& Robertson, 1996); it can therefore be used to detect specific activation in restricted brain sites. The increased c-fos expression does not seem to occur in cholinergic cells within the MSA, as colocalization of antiChAT and anti-c-fos antibodies was never observed. As previously mentioned, the cytoarchitectonic relationship between histaminergic and cholinergic cells is not known. In the MSA-DB there are subpopulations of parvalbumin-positive GABAergic neurons, interspersed with the cholinergic cells, that project to the hippocampus (Kiss et al., 1990; Van der Zee \& Luiten, 1994). In the medial septum there are also peptide-containing neurons (Gall \& Moore, 1984), in particular galanin-positive cells, giving rise to septo-hippocampal efferents (Senut et al., 1989). Given the complexity of the local circuitry within the medial septum and also in relation to the efferent projections (Onteniente et al., 1986; Onteniente et al., 1987; Senut et al., 1989), several plausible synaptic arrangements can be envisaged to explain the effect of histaminergic compounds on both $\mathrm{ACh}$ release in the hipocampus and c-fos expression in the septum.

Increased hippocampal ACh release by histaminergic agents may have implications for the treatment of disorders associated with impaired septo-hippocampal cholinergic functions. Treatment strategies that take advantage of noncholinergic drugs potentiating cholinergic functions may produce beneficial effects on disorders associated with impaired cholinergic functions, such as Alzheimer's disease (Buccafusco \& Terry, 2000). This indirect approach appears preferable to cholinomimetic strategies, because cholinergic drugs have resulted in greater stimulation of inhibitory autoreceptors either by increasing the half-life of acetylcholine in the synaptic cleft (Davis et al., 1992), or by directly activating these receptors due to the poor selectivity of the agonists available (Gauthier et al., 1991). The histaminergic system might well represent a target for these new therapies. The implications of the present study and the report that $\mathrm{H}_{3}$ receptor antagonists improve learning and memory in senescenceaccelerated mice (Meguro et al., 1995) and scopolamine-impaired (Giovannini et al., 1999) rats support this contention.

\section{Acknowledgements}

This work was supported by grants 40 and $60 \%$ from M.U.R.S.T-Universitá di Firenze, Italy.

\section{Abbreviations}

ACh, acetylcholine; BSA, bovine serum albumin; ChAT, choline acetyltransferase; MSA-DB, medial septum-diagonal band; PBS, phosphatebuffered saline; TTX, tetrodotoxin.

\section{References}

Aloisi, A.M., Casamenti, F., Scali, C., Pepeu, G. \& Carli, G. (1997) Effects of novelty, pain and stress on hippocampal extracellular acetylcholine levels in male rats. Brain Res., 748, 219-226.

Alves-Rodrigues, A., Timmerman, H., Willems, E., Lemstra, S., Zuiderveld, O.P. \& Leurs, R. (1998) Pharmacological characterisation of the histamine H3 receptor in the rat hippocampus. Brain Res., 788, 179-186.

Arrang, J.M., Garbarg, M., Lancelot, J.C., Lecomte, J.M., Pollard, H., Robba, M., Schunack, W. \& Schwartz, J.C. (1987) Highly-potent and selective ligands for histamine- $\mathrm{H}_{3}$ receptors. Nature, 327, 117-123.

Arrang, J.M., Garbarg, M. \& Schwartz, J.C. (1983) Auto-inhibition of brain histamine release mediated by a novel class $\left(\mathrm{H}_{3}\right)$ of histamine receptor. Nature, 302, 832-837.

Bacciottini, L., Mannaioni, P.F., Chiappetta, M., Giovannini, M.G. \& Blandina, P. (1999) Acetylcholine release from hippocampus of freely moving rats is modulated by thioperamide and cimetidine. Inflamm. Res., 48, S63-S64.

Bacciottini, L., Passani, M.B., Mannaioni, P.F. \& Blandina, P. (2001) Interactions between histaminergic and cholinergic systems in learning and memory. Behav. Brain Res., 124, 183-194.

Blandina, P., Giorgetti, M., Bartolini, L., Cecchi, M., Timmerman, H., Leurs, R., Pepeu, G. \& Giovannini, M.G. (1996) Inhibition of cortical acetylcholine release and cognitive performance by histamine $\mathrm{H}_{3}$ receptor activation in rats. Br. J. Pharmacol., 119, 1656-1664.

Blandina, P., Knott, P., Leung, L.K.H. \& Green, J.P. (1989) Stimulation of the histamine $\mathrm{H}_{2}$ receptor in the rat hypothalamus releases endogenous norepinephrine. J. Pharmacol. Exp. Ther., 249, 44-51.

Blandina, P., Mannaioni, P.F. \& Giovannini, M.G. (2001) Histamine Receptors activate MAPK signaling pathway in rat hippocampus. Neurosci. Abstr., 27, 513.12

Brito, G.N. \& Brito, L.S. (1990) Septohippocampal system and the prelimbic sector of frontal cortex: a neuropsychological battery analysis in the rat. Behav. Brain Res., 36, 127-146.

Brown, R.E., Stevens, D.R. \& Haas, H.L. (2001) The physiology of brain histamine. Prog. Neurobiol., 63, 637-672.

Buccafusco, J.J. \& Terry, A.V. Jr (2000) Multiple central nervous system targets for eliciting beneficial effects on memory and cognition. J. Pharmacol. Exp. Ther., 295, 438-446.

Calcutt, R.C., Ganellin, C.R., Griffiths, R., Leigh, B.K., Maguire, J.P., Mitchell, R.C., Mylec, M.E., Parson, M.E., Smith, I.R. \& Young, R.C. (1988) Zolantidine (SK \& F95282) is a potent selective brain-penetrating histamine $\mathrm{H}_{2}$ receptor antagonist. Br. J. Pharmacol., 93, 69-78.

Ceccarelli, I., Casamenti, F., Massafra, C., Pepeu, G., Scali, C. \& Aloisi, A.M. (1999) Effects of novelty and pain on behavior and hippocampal extracellular ACh levels in male and female rats. Brain Res., 815, 169-176.

Cecchi, M., Passani, M.B., Bacciottini, L., Mannaioni, P.F. \& Blandina, P. (2001) Cortical acetylcholine release elicited by stimulation of histamine $\mathrm{H} 1$ receptors in the nucleus basalis magnocellularis: a dual probe microdialysis study in the freely moving rat. Eur. J. Neurosci., 13, 68-78.

Consolo, S., Arnaboldi, S., Giorgi, S., Russi, G. \& Ladinsky, H. (1994) 5-HT 4 receptor stimulation facilitates acetylcholine release in rat frontal cortex. Neuroreport, 5, 1230-1232. 
Davis, K., Thai, L., Gamzu, E., Davis, C., Woolson, R., Gracon, S., Drachman, D., Schneider, L., Whitehouse, P., Hoover, T., Morris, J., Kawas, C., Knopman, D., Earl, N., Kumar, V., Doody, R. \& The Tacrine Collaborative Study Group (1992) A double-blind placebo-controlled multicenter study of tacrine for Alzheimer's disease. N. Engl. J. Med., 327, 1253-1259.

De Lacalle, S., Lim, C., Sobreviela, T., Mufson, E.J., Hersh, L.B. \& Saper, C.B. (1994) Cholinergic innervation in the human hippocampal formation including the enthorhinal cortex. J. Comp. Neurol., 345, 321-344.

DeBoer, P. \& Abercrombie, E.D. (1996) Physiological release of striatal acetylcholine in vivo: Modulation by $\mathrm{D}_{1}$ and $\mathrm{D}_{2}$ receptor subtypes. J. Pharmacol. Exp. Ther., 277, 775-783.

Decker, M.W. \& McGaugh, J.L. (1991) The role of interactions between the cholinergic system and other neuromodulatory systems in learning and memory. Synapse, 7, 151-168.

Dickinson-Anson, H., Aubert, I., Gage, F.H. \& Fisher, L.J. (1998) Hippocampal grafts of acetylcholine-producing cells are sufficient to improve behavioural performance following a unilateral fimbria-fornix lesion. Neuroscience, 84, 771-781.

Dragunow, M. \& Faull, R. (1989) The use of c-fos as a metabolic marker in neuronal pathway tracing. J. Neurosci. Meth., 29, 261-265.

Drutel, G., Peitsaro, N., Karlstedt, K., Wieland, K., Smit, M., Timmerman, H., Panula, P. \& Leurs, R. (2001) Identification of rat H3 receptor isoforms with different brain expression and signaling properties. Mol. Pharmacol., 59, 18.

Durant, G.J., Emmett, J.C. \& Ganellin, C.R. (1977) Cyanoguanidine-thiourea equivalence in the development of the histamine $\mathrm{H}_{2}$ receptor antagonist, cimetidine. J. Med. Chem., 20, 901-906.

Dutar, P., Lamour, Y., Rascol, O. \& Jobert, A. (1986) Septo-hippocampal neurons in the rat: further study of their physiological and pharmacological properties. Brain Res., 365, 325-334.

English, J.D. \& Sweatt, J.D. (1996) Activation of p42 mitogen-activated protein kinase in hippocampal long-term potentiation. J. Biol. Chem., 271 , 24329-24332.

Everitt, B.J. \& Robbins, T.W. (1997) Central cholinergic systems and cognition. Annu. Rev. Psychol., 48, 649-684.

Flood, J.F., Uezu, K. \& Morley, J.E. (1998) Effect of histamine H2 and H3 receptor modulation in the septum on post-training memory processing. Psychopharmacology, 140, 279-284.

Gall, C. \& Moore, R.Y. (1984) Distribution of enkephalin, substance P, tyrosine hydroxylase, and 5-hydroxytriptamine immunoreactivity in the septal region of the rat. J. Comp. Neurol., 225, 212-227.

Garbarg, M., Arrang, J.M., Llorens-Cortes, C., Pollard, H., Rouleau, A., Schwartz, J.-C., Dam Trung Tuong, M., Lipp, R., Stark, H., Schunack, W. \& Lecomte, J.M. (eds), (1991) Autoreceptors and Heteroreceptors Evidenced by Histamine H3 Receptor Ligands. Pergamon, Oxford (UK).

Gauthier, S., Gauthier, L., Brochard, R., Quirion, R. \& Sultan, S. (1991) Treatment of Alzheimer's disease: hopes and reality. Can. J. Neurol. Sci., 18, 439-441.

Gaykema, R.P.A., Luiten, P.G.M., Nyakas, C. \& Traber, J. (1990) Cortical projection patterns of the medial septum-diagonal band complex. J. Comp. Neurol., 293, 103-124.

Giorgetti, M., Bacciottini, L., Giovannini, M.G., Colivicchi, M.A., Goldfarb, J. \& Blandina, P. (2000) Local GABAergic inhibitory tone of acetylcholine release from the cortex of freely moving rats. Eur. J. Neurosci., 12, 19411948.

Giovannelli, L., Shiromani, P.J., Jirikowski, G.F. \& Bloom, F.E. (1990) Oxytocin neurons in the rat hypothalamus exhibit c-fos immunorecativity upon osmotic stress. Brain Res., 531, 299-303.

Giovannini, M.G., Bartolini, L., Bacciottini, L., Greco, L. \& Blandina, P. (1999) Effects of histamine $\mathrm{H}_{3}$ receptor agonists and antagonists on cognitive performance and scopolamine-induced amnesia. Behav. Brain Res., 104, 147-155.

Giovannini, M.G., Ceccarelli, I., Molinari, B., Cecchi, M., Goldfarb, J. \& Blandina, P. (1998) Serotonergic modulation of acetylcholine release from cortex of freely moving rats. J. Pharmacol. Exp. Ther., 285, 1219-1225.

Givens, B. \& Olton, D.S. (1994) Local modulation of basal forebrain: effects on working and reference memory. J. Neurosci., 14, 3578-3587.

Givens, B. \& Sarter, M. (1997) Modulation of cognitive processes by transsynaptic activation of the basal forebrain. Behav. Brain Res., 84, 1-22.

Gorelova, N. \& Reiner, P.B. (1996) Histamine depolarizes cholinergic septal neurons. J. Neurophysiol., 75, 707-714.

Herrera, D.G. \& Robertson, H.A. (1996) Activation of c-fos in the brain. Prog. Neurobiol., 50, 83-107.

Herrera-Marschitz, M., Goiny, M., Utsumi, H., Ferre, S., Hakansson, L.,
Nordberg, A. \& Ungerstedt, U. (1990) Effect of unilateral nucleus basalis lesion on cortical and striatal acetylcholine release monitored in vivo with microdialysis. Neurosci. Lett., 110, 172-179.

Hill, S.J. (1990) Distribution, properties, and functional characteristics of three classes of histamine receptor. Pharmacol. Rev., 42, 45-83.

Hill, S.J., Ganellin, C.R., Timmerman, H., Schwartz, J.C., Shankley, N.P., Young, J.M., Schunack, W., Levi, R. \& Haas, H.L. (1997) International union of Pharmacology. XIII. Classification of histamine receptors. Pharmacol. Rev., 49, 253-278.

Himmelheber, A.M., Fadel, J., Sarter, M. \& Bruno, J.P. (1998) Effects of local cholinesterase inhibition on acetylcholine release assessed simultaneously in prefrontal and fronto-parietal cortex. Neuroscience, 86, 949-957.

Inagaki, N., Yamatodani, A., Ando-Yamamoto, M., Tohyama, M., Watanabe, T. \& Wada, H. (1988) Organization of histaminergic fibers in the rat brain. J. Comp. Neurol., 273, 283-300.

Inglis, F.M. \& Fibiger, H.C. (1995) Increases in hippocampal and frontal cortical acetylcholine release associated with the presentation of sensory stimuli. Neuroscience, 66, 81-86.

Ison, R.R. \& Casy, A.F. (1971) Structural influence upon antihistamine activity: 3-amino-1-aryl-1-(2-pyridyl)-propenes and related compounds. J. Pharm. Pharmacol., 23, 848-856.

Johnson, C.L. (1982) Histamine receptors and cyclic nucleotide. In Ganellin, R. \& Parson, M. (eds), Pharmacology of Histamine Receptors. J Wright Ltd, London, pp. 146-216.

Karlstedt, K., Senkas, A., Åhman, M. \& Panula, P. (2001) regional expression of the histamine $\mathrm{H}_{2}$ receptor in adult and developing rat brain. Neuroscience, 102, 201-208.

Kiss, J.P., Atel, A., Baimbridge, K. \& Freund, T. (1990) Topographical localization of neurons containing parvalbumine and choline acetyltransferasde in the medial septum-diagonal band region of the rat. Neuroscience, 36, 61-72.

Lamour, Y., Dutar, P. \& Jobert, A. (1984) Septo-hippocamapl and other medial septum-diagonal band neurons: electrophysiological and pharmacological properties. Brain Res., 309, 227-239.

Lee, B.H., Lamour, Y. \& Bassant, M.H. (1991) Iontophoretic study og medial septal neurons in the anaesthetized rat. Neurosci. Lett., 128, 29-32.

Leurs, R., Blandina, P., Tedford, C. \& Timmerman, H. (1998) Therapeutic potential of histamine $\mathrm{H}_{3}$ receptor agonists and antagonists. Trends Pharmacol. Sci., 19, 177-183.

Leurs, R., Smit, M.J. \& Timmerman, H. (1995) Molecular and pharmacological aspects of histamine receptors. Pharmacol. Ther., 66 , 413-463

Lewis, P.R. \& Shute, C.C.D. (1967) The cholinergic limbic system: projections to hippocampal formation, medial cortex nuclei of the ascending cholinergic reticular system and the subfornical organ and supra-optic crest. Brain, 90, 521-537.

Lewis, P.R., Shute, C.C.D. \& Silver, A. (1967) Confirmation from choline acetylase analyses of a massive cholinergic innervation to the rat hippocampus. J. Physiol. (Lond.), 191, 215-224.

Ligneau, X., Lin, J.-S., Vanni-Mercier, G., Jouvet, M., Muir, J.L., Ganellin, C.R., Stark, H., Elz, S., Schunack, W. \& Schwartz, J.C. (1998) Neurochemical and behavioral effects of ciproxifan, a potent histamine $\mathrm{H}_{3}$-receptor antagonist. J. Pharmacol. Exp. Ther., 287, 658-666.

Mark, G.P., Rada, P., Pothos, E. \& Hoebel, B.G. (1992) Effects of feeding and drinking on acetylcholine release in the nucleus accumbens, striatum and hippocampus of freely behaving rats. J. Neurochem., 581, 2269-2274.

McGaugh, J.L. \& Izquierdo, I. (2000) The contribution of pharmacology to research on the mechanisms of memory formation. Trends Pharmacol. Sci. 21, 208-210.

Meguro, K.-I., Yanai, K., Sakai, N., Sakurai, E., Maeyama, K., Sasaki, H. \& Watanabe, T. (1995) Effects of thioperamide, a histamine H3 antagonist, on the step-through passive avoidance response and histidine decarboxylase activity in senescence-accelerated mice. Pharmacol. Biochem. Behav., 50, 321-325.

Mesulam, M.M., Mufson, E.J., Wainer, B.H. \& Levey, A.I. (1983) Central cholinergic pathways in the rat: an overview based on an alternative nomenclature (Ch1-Ch6). Neuroscience, 10, 1185-1201.

Mizuno, T., Arita, J. \& Kimura, F. (1994) Spontaneous acetylcholine release in the hippocampus exhibits a diurnal variation in both young and old rats. Neurosci. Lett., 178, 271-274.

Mochizuki, T., Okakura-Mochizuki, K., Horii, A., Yamamoto, Y. \& Yamatodani, A. (1994) Histaminergic modulation of hippocampal acetylcholine release in vivo. J. Neurochem., 62, 2275-2282.

Moor, E., Schirm, E., Jacsó, J. \& Westerink, B.H.C. (1998) Involvement of medial septal glutamate and $\mathrm{GABA}_{\mathrm{A}}$ receptors in behaviour-induced 
acetylcholine release in the hippocampus: a dual probe microdialysis study. Brain Res., 789, 1-8.

Nail-Boucherie, K., Dourmap, N., Jaffard, R. \& Costentin, J. (2000) Contextual fear conditioning is associated with an increase of acetylcholine release in the hippocampus of rat. Cognit. Brain Res., 9, 193-197.

Nicoll, R.A. (1985) The septo-hippocampal projection: a model cholinergic pathway. Trends Neurosci., 8, 533-536.

Nilsson, O.G., Kalén, P., Rosengren, E. \& Biöklund, A. (1990) Acetylcholine release in the rat hippocampus as studied by microdialysis is dependent on axonal impulse flow and increases during behavioural activation. Neuroscience, 36, 325-338.

Nyakas, C., Luiten, P.G.M., Spencer, D.G. \& Traber, J. (1987) Detailled projection patterns of septal and diagonal band efferents to the hippocampus in the rat with emphasis on innervation of CA1 and dentate gyrus. Brain Res. Bull., 18, 533-545.

Onteniente, B., Geffard, M., Campistron, G. \& Calas, A. (1987) An ultrastructural study of GABA-immunoreactive neurons and terminals in the septum of the rat. J. Neurosci., 7, 48-54.

Onteniente, B., Tago, H., Kimura, H. \& Maeda, T. (1986) Distribution of gamma-aminobutyric acid-immunoreactive neurons and terminals in the septum of the rat. J. Comp. Neurol., 248, 422-430.

Panula, P., Pirvola, U., Auvinen, S. \& Airaksinen, M.N. (1989) Histamineimmunoreactive nerve fibers in the rat brain. Neuroscience, 28, 585-610.

Panula, P., Yang, H.Y. \& Costa, E. (1984) Histamine-containing neurons in rat hypothalamus. Proc. Natl Acad. Sci. USA, 81, 2572-2576.

Parson, M.E., Owen, D.A.A., Ganellin, C.R. \& Durant, C.J. (1977) Dimaprit -[S-[3-(N,N-dimethyl-amino) propyl]isothiourea]- a highly specific histamine $\mathrm{H}_{2}$-receptor agonist: pharmacology. Agents Actions, 7, 31-38.

Passani, M.B., Bacciottini, L., Mannaioni, P.F. \& Blandina, P. (2000) Central histaminergic system and cognitive processes. Neurosci. Biobehav. Rev., 24, 107-114.

Passani, M.B. \& Blandina, P. (1998) Cognitive implications for $\mathrm{H}_{3}$ and 5- $\mathrm{HT}_{3}$ receptors modulation of cortical cholinergic function: a parallel story. Meth. Find. Exp. Clin. Pharmacol., 20, 725-733.

Passani, M.B., Cangioli, I., Baldi, E., Bucherelli, C., Mannaioni, P.F. \& Blandina, P. (2001) Histamine $\mathrm{H}_{3}$ receptor-mediated impairment of contextual fear conditioning, and in-vivo inhibition of cholinergic transmission in the rat basolateral amygdala. Eur. J. Neurosci., 14, 15221532.

Paxinos, G. \& Watson, C. (1982). The Rat Brain in Stereotaxic Coordinates. Academic Press, New York.

Pepeu, G. \& Blandina, P. (1998) The acetylcholine, GABA, glutamate triangle in the rat forebrain. J. Physiol. (Paris), 92, 351-355.

Pollard, H., Moreau, J., Arrang, J.M. \& Schwartz, J.-C. (1993) A detailed autoradiographic mapping of histamine $\mathrm{H}_{3}$ receptors in rat brain areas. Neuroscience, 52, 169-189.

Segal, M. (1986) Properties of rat medial septal neurons recorded in vitro. J. Physiol. (Lond.), 379, 309-330.

Senut, M., Menetrey, D. \& Lamour, Y. (1989) Cholinergic and peptidergic projections from the medial septum and the nucleus of the diagonal band of Broca to dorsal hippocampus, cingulate cortex and olfactory bulb: a combined wheatgerm agglutinin-apohorseradish peroxidase-gold immunohistochemical study. Neuroscience, 30, 385-403.

Sweeney, J.E., Lamour, Y. \& Bassant, M.H. (1992) Arousal-dependent properties of medial septal neurons in the unanesthetized rat. Neuroscience, 48, 353-362.

Takeda, N., Inagaki, S., Taguchi, Y., Tohyama, M., Watanabe, T. \& Wada, H. (1984) Origins of histamine-containing fibers in cerebral cortex of rats studied by immunohistochemistry with histidine decarboxylase as a marker and transection. Brain Res., 323, 55-63.

Van der Zee, E. \& Luiten, P. (1994) Cholinergic and GABA-ergic neurons in the rat medial septum express muscarinic acetylcholine receptors. Brain Res., 652, 263-272.

Vizuete, M.L., Traiffort, E., Bouthenet, M.L., Ruat, M., Souil, E., TardivelLacombe, J. \& Schwartz, J.C. (1997) Detailed mapping of the histamine $\mathrm{H}_{2}$ receptor and its gene transcripts in guinea-pig brain. Neuroscience, $\mathbf{8 0}, 321$ 343.

Wada, H., Inagaki, N., Yamatodani, A. \& Watanabe, T. (1991) Is the histaminergic neuron system a regulatory center for whole-brain activity? Trends Neurosci., 14, 415-418.

Watanabe, T., Taguchi, Y., Shiosaka, S., Tanaka, J., Kubota, H., Terano, Y., Tohyama, M. \& Wada, H. (1984) Distribution of the histaminergic neuron system in the central nervous system of rats: a fluorescent immunohistochemical analysis with histidine decarboxylase as a marker. Brain Res., 295, 13-25.

Westerink, B.H.C. \& de Vries, J.B. (1996) A new method to estimate the migration rate of centrally acting drugs from microdialysis probes through brain tissues in conscious animals. In Gonzáles-Mora, J.L., Borges, R. \& Mas, M. (eds), Monitoring Molecules in Neuroscience. University of La Laguna, Tenerife, Spain, pp. 9-10.

Wouterlood, F.G., Gaykema, R.P., Steinbusch, H.W., Watanabe, T. \& Wada, H. (1988) The connections between the septum-diagonal band complex and histaminergic neurons in the posterior hypothalamus of the rat. Anterograde tracing with Phaseolus vulgaris-leucoagglutinin combined with immunocytochemistry of histidine decarboxilase. Neuroscience, 26, 827845 .

Wu, M., Shanabrough, M., Leranth, C. \& Alreja, M. (2000) Cholinergic excitation of septohippocampal GABA but not cholinergic neurons: implications for learning and memory. J. Neurosci., 20, 3900-3908. 